\title{
Effect of Type of Concentrated Sweet Cream Buttermilk on the Manufacture, Yield, and Functionality of Pizza Cheese
}

\author{
S. Govindasamy-Lucey, ${ }^{\star 1}$ T. Lin, $\dagger$ J. J. Jaeggi, ${ }^{*}$ C. J. Martinelli, ${ }^{*}$ M. E. Johnson, ${ }^{*}$ and J. A. Lucey† \\ *Wisconsin Center for Dairy Research, and \\ †Department of Food Science, University of Wisconsin-Madison, 53706
}

\begin{abstract}
Sweet cream buttermilk (SCB) is a rich source of phospholipids (PL). Most SCB is sold in a concentrated form. This study was conducted to determine if different concentration processes could affect the behavior of SCB as an ingredient in cheese. Sweet cream buttermilk was concentrated by 3 methods: cold $\left(<7^{\circ} \mathrm{C}\right) \mathrm{UF}$, cold reverse osmosis (RO), and evaporation (EVAP). A washed, stirred-curd pizza cheese was manufactured using the 3 different types of concentrated SCB as an ingredient in standardized milk. Cheesemilks of casein:fat ratio of 1.0 and final casein content $\sim 2.7 \%$ were obtained by blending ultrafiltered (UF)-SCB retentate (19.9\% solids), RO-SCB retentate $(21.9 \%$ solids), or EVAP-SCB retentate $(36.6 \%$ solids) with partially skimmed milk (11.2\% solids) and cream (34.6\% fat). Control milk (11.0\% solids) was standardized by blending partially skimmed milk with cream. Cheese functionality was assessed using dynamic low-amplitude oscillatory rheology, UW Meltprofiler (degree of flow after heating to $60^{\circ} \mathrm{C}$ ), and performance of cheese on pizza. Initial trials with SCB-fortified cheeses resulted in $\sim 4$ to $5 \%$ higher moisture (51 to $52 \%$ ) than control cheese $(\sim 47 \%)$. In subsequent trials, procedures were altered to obtain similar moisture content in all cheeses. Fat recoveries were significantly lower in RO- and EVAP-SCB cheeses than in control or UF-SCB cheeses. Nitrogen recoveries were not significantly different but tended to be slightly lower in control cheeses than the various SCB cheeses. Total PL recovered in SCB cheeses $(\sim 32$ to $36 \%)$ were lower than control ( 41\%), even though SCB is high in PL. From the rheology test, the loss tangent curves at temperatures $>40^{\circ} \mathrm{C}$ increased as cheese aged up to a month and were significantly lower in SCB cheeses than the control, indicating lower meltability. Degree of flow in all the cheeses was similar regardless of the treatment used,
\end{abstract}

Received October 17, 2006.

Accepted February 1, 2007.

${ }^{1}$ Corresponding author: rani@cdr.wisc.edu and as cheese ripened, it increased for all cheeses. Trichloroacetic acid-soluble $\mathrm{N}$ levels were similar in the control and SCB-fortified cheese. On baked pizza, cheese made from milk fortified with UF-SCB tended to have the lowest amount of free oil, but flavor attributes of all cheeses were similar. Addition of concentrated SCB to standardize cheesemilk for pizza cheese did not adversely affect functional properties of cheese but increased cheese moisture without changes in manufacturing procedure.

Key words: sweet cream buttermilk, pizza cheese, cheese yield, melt

\section{INTRODUCTION}

Sweet cream buttermilk (SCB) has gained attention as a by-product that could be fractionated to yield functional ingredients (Corredig et al., 2003). Much of the functional properties of SCB are attributed to the higher ratio of $\mathrm{CN}$ compared with other proteins and to the milk fat globule membrane (MFGM) materials (Corredig and Dalgleish, 1998; Corredig et al., 2003). Sweet cream buttermilk has been recognized as a good source of phospholipids (PL; Sachdeva and Buchheim, 1997). Recent nutritional studies have suggested that the consumption of PL (e.g., sphingolipids) may bring health-related benefits (Nava et al., 2000; Modrak et al., 2002). These complex lipids have shown to help with metabolic and age-related diseases, stress responses, and apoptosis (Huwiler et al., 2002; Modrak et al., 2002). Phospholipids are commonly found in cell membranes, brain, and neural tissues; all are impractical sources for lipid isolation. Milk fat globule membrane is a material that contains much bioactive PL (Astaire et al., 2003). Sweet cream buttermilk is a good source of MFGM material and could be used as a functional ingredient in foods. Using SCB as a source of PL may be attractive considering its unique properties, its low cost, and availability (Astaire et al., 2003). Because SCB is a low-solids substance, enriched or concentrated fractions of SCB would be more attractive for use as value-added ingredients in foods. For the dairy industry, it may be advantageous to use concentrated SCB 
as an ingredient to impart health and functional benefits in dairy products.

Studies have been carried out on membrane filtration of SCB and the use of SCB retentates as ingredients in dairy products (Mistry et al., 1996; Poduval and Mistry, 1999; Raval and Mistry, 1999). These results have shown that the addition of UF SCB improved the texture of low-fat cheeses. Most commercial SCB is sold in a concentrated form (due to its low solids content), either as a dried powder, condensed by heat and vacuum (EVAP), or concentrated by membrane filtration. Previous studies have shown that addition of SCB increased the moisture content of reduced-fat cheese (Madsen et al., 1966; Joshi and Thakar, 1993; Mayes et al., 1994; Mistry et al., 1996). Without adjusting the cheese-making procedure, the addition of EVAP-SCB ( 2 to $6 \% \mathrm{wt} / \mathrm{wt}$ ) during manufacture of pizza cheese has been shown to increase the moisture content and result in high-acid cheeses (Govindasamy-Lucey et al., 2006). Using EVAP-SCB as a cheese ingredient at low levels $(\sim 2 \%)$ improves cheese yield without adversely affecting the compositional, rheological, and sensory properties of pizza cheese (when the cheese moisture content was adjusted to be similar to that of the control cheese). Using very high levels of EVAP-SCB causes acid defects because of the high lactose content in the condensed SCB. This issue could be alleviated using UF or diafiltration to produce concentrated SCB with reduced lactose content. Another option is to concentrate SCB using reverse osmosis (RO). The disadvantage of using $\mathrm{RO}$ is that RO, like EVAP, also concentrates the lactose content. The advantage is that only water is produced during $\mathrm{RO}$, which reduces the disposal issues related to permeates produced during UF and microfiltration.

Although previous research has shown that SCB can be potentially used as a value-added ingredient in foods, it is not clear how different concentration processes affect the behavior of SCB in dairy products. The objective of this study was to understand how the addition of differently processed concentrated SCB, that is, by UF, RO, and EVAP, affects cheese yield; composition, including recovery of PL; proteolysis; and functional characteristics during the manufacture of pizza cheese. Furthermore, curd fusion has been reported to be poor in cheeses manufactured with 10 to $25 \%$ UF buttermilk (Mistry et al., 1996). Thus, we also wanted to identify any manufacturing changes that may be necessary to successfully use concentrated SCB in pizza cheese.

\section{MATERIALS AND METHODS}

\section{Standardization}

Fresh, unconcentrated SCB was obtained from a local creamery on several different occasions. The average composition of the SCB is given in Table 1. On each occasion, SCB was concentrated by 3 processes: UF, RO, and EVAP at the Wisconsin Center for Dairy Research. Total solids level of SCB was the parameter used to monitor the progress of these concentration processes. Ultrafiltration was carried out by concentrating SCB to 18 to $20 \%$ solids, at $\sim 2.8 \times 10^{6} \mathrm{~Pa}$ and $<7^{\circ} \mathrm{C}$, by recirculation through a UF unit (APV Americas, Schaumburg, IL) fitted with spiral-wound, polyethersulfone membranes (with a molecular weight cutoff of 10,000 Da; Advanced Membrane Technology, San Diego, CA). To obtain SCB concentrated by RO, SCB was processed to a TS content of 21 to $22 \%$ at $\sim 4.8 \times$ $10^{6} \mathrm{~Pa}$ and $\sim 10^{\circ} \mathrm{C}$ through a RO membrane (Advanced Membrane Technology), which had $99.5 \% \mathrm{NaCl}$ rejection capability. Evaporated SCB concentrate was obtained by evaporating the SCB at 64 to $65^{\circ} \mathrm{C}$ in a custom-made laboratory-scale, single effect, falling filmtype evaporator (HX Paravap, APV Americas) until a TS content of $\sim 36 \%$ was obtained. Once the appropriate TS level was reached, the heat exchanger for the evaporator was switched over to chilled water $\left(2\right.$ to $\left.4^{\circ} \mathrm{C}\right)$, and the concentrated SCB was recirculated until it cooled down to $\sim 3$ to $4^{\circ} \mathrm{C}$. Thus, SCB was concentrated via UF, RO, and EVAP to TS contents of $19.9 \%(9.94 \% \pm 0.82$ $\mathrm{CN}), 21.9 \%(6.05 \% \pm 0.18 \mathrm{CN})$, and $36.6 \%(9.50 \% \pm 0.36$ $\mathrm{CN}$ ), respectively (Table 1 ). The SCB concentrates were stored overnight at $4^{\circ} \mathrm{C}$ and blended with part-skim milk and cream the following morning to give standardized cheesemilks.

Raw whole milk and cream were obtained from the University of Wisconsin-Madison dairy plant on the day before cheese making. Raw whole milk was partially skimmed (fat content $=2.32 \% \pm 0.09$ ).

Four types of cheesemilks were prepared: control, milks standardized with UF-SCB, RO-SCB, and EVAPSCB (Table 2). Control milk was standardized by blending the part-skim milk with cream to an average of $10.98 \%$ solids $(2.5 \% \pm 0.08 \mathrm{CN})$ with a mean $\mathrm{CN}$ :fat ratio of $\sim 1.0$ (Table 3 ). The other 3 SCB standardized cheesemilks, UF-SCB, RO-SCB, and EVAP-SCB, were prepared by the addition of the appropriate amount of the concentrated SCB to part-skim milk $(11.16 \%$ TS, $2.49 \% \pm 0.0 \mathrm{CN})$ and cream $(41.18 \% \pm 2.92 \mathrm{TS}, 1.42 \%$ $\pm 0.13 \mathrm{CN}$; Table 1). Cheesemilks of all 4 treatments were standardized to have a CN:fat ratio of $\sim 1: 0$; however, cheesemilks with added SCB had $\sim 2.7 \% \mathrm{CN}$, whereas cheesemilk from control treatment had $\sim 2.5 \%$ $\mathrm{CN}$. The $\mathrm{CN}$ content in each of the 3 experimental cheesemilks was adjusted to $\sim 2.7 \%$ based on our previous studies (Govindasamy-Lucey et al., 2006) in which the quality of the cheeses was not compromised when this amount of $\mathrm{CN}$ was used for pizza cheese making. 
Table 1. Composition of part-skim milk, unconcentrated sweet cream buttermilk (SCB), and the various types of processed buttermilk (UFSCB, RO-SCB, and EVAP-SCB) and cream used in the preparation of the standardized cheesemilks for the different treatments ${ }^{1}$

\begin{tabular}{|c|c|c|c|c|c|c|c|c|}
\hline Treatment $^{2}$ & $\mathrm{TS}, \%$ & $\mathrm{CN},{ }^{3} \%$ & $\begin{array}{c}\text { Total } \\
\text { protein, }{ }^{4} \%\end{array}$ & $\begin{array}{c}\text { True } \\
\text { protein, }{ }^{5} \%\end{array}$ & $\begin{array}{c}\text { Lactose } \\
\text { content, \% }\end{array}$ & $\begin{array}{l}\text { Total } \\
\text { fat, } \%\end{array}$ & $\begin{array}{c}\text { Total Ca, mg/ } \\
100 \mathrm{~g} \text { of sample }\end{array}$ & $\begin{array}{l}\text { Total Ca, } \\
\mathrm{mg} / \mathrm{g} \text { of } \mathrm{CN}\end{array}$ \\
\hline Part-skim milk & $11.16 \pm 0.06$ & $2.49 \pm 0.07$ & $3.22 \pm 0.05$ & $3.03 \pm 0.07$ & $\mathrm{ND}^{6}$ & $2.32 \pm 0.09$ & ND & ND \\
\hline Unconcentrated SCB & $8.26 \pm 0.46$ & $2.22 \pm 0.10$ & $2.66 \pm 0.11$ & $2.49 \pm 0.13$ & ND & $0.75 \pm 0.11$ & $82.6 \pm 4.2$ & $38.0 \pm 0.1$ \\
\hline RO-SCB & $21.94 \pm 0.43$ & $6.05 \pm 0.18$ & $7.05 \pm 0.18$ & $6.67 \pm 0.19$ & $10.87 \pm 0.27$ & $2.02 \pm 0.17$ & $227.8 \pm 2.2$ & $37.7 \pm 1.3$ \\
\hline EVAP-SCB & $36.59 \pm 0.73$ & $9.50 \pm 0.36$ & $10.51 \pm 0.42$ & $10.51 \pm 0.42$ & $18.30 \pm 0.25$ & $3.22 \pm 0.28$ & $388.0 \pm 9.5$ & $39.7 \pm 1.9$ \\
\hline Cream & $41.18 \pm 2.92$ & $1.42 \pm 0.13$ & $1.88 \pm 0.17$ & ND & ND & $34.56 \pm 2.72$ & ND & ND \\
\hline
\end{tabular}

${ }^{1}$ Milks, unconcentrated SCB, and concentrated SCB and cream from 3 different batches, and results are from 3 complete replicates of the treatments done on different days.

${ }^{2} \mathrm{RO}=$ reverse osmosis; EVAP $=$ evaporation.

${ }^{3}($ Total $\% \mathrm{~N}-\%$ non-CN N) $\times 6.36$.

${ }^{4}$ Total percentage of $\mathrm{N} \times 6.35$.

$5($ Total $\% \mathrm{~N}-\% \mathrm{NPN}) \times 6.35$.

${ }^{6} \mathrm{ND}=$ not determined.

\section{Cheese Manufacture and Sampling Procedures}

Three replicate cheese-making trials were carried out. In each trial, on the day of blending, pizza cheese was manufactured from each of the 4 cheesemilks (control, UF-SCB, RO-SCB, and EVAP-SCB) by licensed Wisconsin cheesemakers in the University of Wisconsin-Madison dairy processing pilot plant using our standard pizza cheese manufacturing protocol (Chen and Johnson, 2001) as described by Govindasamy-Lucey et al. (2005). The control and experimental vats were filled with $227 \mathrm{~kg} \pm 0$ and $204 \mathrm{~kg} \pm 0$ of pasteurized milk, respectively. In all experimental vats, milk volume was based on $\mathrm{CN}$ content compared with the control vat to keep actual cheese yield similar in all vats. The amount of starters and rennet added to all vats was standardized on the $\mathrm{CN}$ content of the standardized milks (Govindasamy-Lucey et al., 2005).

The coagula were cut with $6-\mathrm{mm}$ knives at $\mathrm{pH} 6.27$ \pm 0.06 on similar firmness as evaluated subjectively by an experienced, licensed Wisconsin cheesemaker. The temperature of the vat was raised to the cooking temperature of $36.7^{\circ} \mathrm{C}$ over $20 \mathrm{~min}$. After reaching the cooking temperature, each vat was cooked at that temperature with stirring for $\sim 15 \mathrm{~min}$. The whey was drained over $\sim 20 \mathrm{~min}$. At completion of drain, $36.3 \mathrm{~kg}$ of water at $15.5^{\circ} \mathrm{C}$ was added to the curd. The curd sat in the water slurry for a period of $\sim 20$ min with a slurry temperature of $26.1^{\circ} \mathrm{C}$. The water was then drained in $\sim 15$ min. The curd from all vats was then salted in 3 equal applications over a 15-min period at a rate of $102 \pm 4$ $\mathrm{g} / \mathrm{kg}$ of CN. The curd was packed into 9-kg Wilson hoops and pressed for $3 \mathrm{~h}$ at $\sim 23^{\circ} \mathrm{C}$. Press whey was collected and sampled from the first salt application through 1 $\mathrm{h}$ of pressing. After pressing, the cheeses were placed in a cooler $\left(7^{\circ} \mathrm{C}\right)$ overnight. The following morning, the cheeses were removed from the molds and weighed The cheeses were vacuum-packaged in Cryovac standard clear bags (9Fv86, Cryovac North America, Duncan, $\mathrm{SC})$ and aged at $7^{\circ} \mathrm{C}$.

\section{Compositional Analyses}

All compositional analyses were carried out in triplicate. Unconcentrated SCB, UF-SCB, RO-SCB, EVAPSCB, milk, whey, wash water, and press whey samples were analyzed for fat by Mojonnier (AOAC, 2000), protein (total percentage of $\mathrm{N} \times 6.35$ ) by Kjeldahl (AOAC, 2000), CN (AOAC, 2000), lactose (AOAC, 2000), TS (Green and Park, 1980), and NPN (AOAC, 2000).

Table 2. Percentage weights of part-skim milk, cream, and concentrated buttermilk used in the preparation of the standardized cheesemilks for the different treatments ${ }^{1}$

\begin{tabular}{|c|c|c|c|c|}
\hline Treatment $^{2}$ & Control & UF-SCB & RO-SCB & EVAP-SCB \\
\hline Part-skim milk, \% & $99.73 \pm 0.39$ & $94.73 \pm 0.13$ & $90.11 \pm 0.29$ & $94.78 \pm 0.07$ \\
\hline UF-SCB, \% & - & $3.97 \pm 0.04$ & - & - \\
\hline RO-SCB, \% & - & - & $8.42 \pm 0.07$ & - \\
\hline EVAP-SCB, \% & - & - & - & $3.97 \pm 0.04$ \\
\hline Cream, \% & $0.27 \pm 0.03$ & $1.30 \pm 0.09$ & $1.48 \pm 0.03$ & $1.26 \pm 0.02$ \\
\hline
\end{tabular}

${ }^{1}$ Means of 3 complete replicates of the treatments done on different days.

${ }^{2} \mathrm{RO}=$ reverse osmosis; EVAP = evaporation; $\mathrm{SCB}=$ sweet cream buttermilk. 
Table 3. Composition ${ }^{1}$ of pasteurized standardized cheesemilks, drain whey, press whey, and cheeses

\begin{tabular}{|c|c|c|c|c|c|c|}
\hline \multirow[b]{2}{*}{ Component } & \multicolumn{4}{|c|}{ Treatment $^{2}$} & \multirow[b]{2}{*}{ SEM } & \multirow[b]{2}{*}{$P$-valu } \\
\hline & Control & UF-SCB & RO-SCB & EVAP-SCB & & \\
\hline \multicolumn{7}{|l|}{ Standardized cheesemilk } \\
\hline TS, \% & $10.96^{\mathrm{c}}$ & $11.54^{\mathrm{b}}$ & $12.03^{\mathrm{a}}$ & $12.07^{\mathrm{a}}$ & 0.074 & $<0.0001$ \\
\hline Milk fat, $\%$ & $2.45^{\mathrm{b}}$ & $2.79^{\mathrm{a}}$ & $2.76^{\mathrm{a}}$ & $2.76^{\mathrm{a}}$ & 0.023 & $<0.0001$ \\
\hline Total protein, ${ }^{3} \%$ & $3.22^{\mathrm{b}}$ & $3.50^{\mathrm{a}}$ & $3.49^{\mathrm{a}}$ & $3.50^{\mathrm{a}}$ & 0.020 & $<0.0001$ \\
\hline True protein, $4 \%$ & $3.03^{\mathrm{b}}$ & $3.30^{\mathrm{a}}$ & $3.28^{\mathrm{a}}$ & $3.29^{\mathrm{a}}$ & 0.022 & $<0.0001$ \\
\hline $\mathrm{CN},{ }^{5} \%$ & $2.51^{\mathrm{b}}$ & $2.75^{\mathrm{a}}$ & $2.75^{\mathrm{a}}$ & $2.74^{\mathrm{a}}$ & 0.018 & $<0.0001$ \\
\hline NPN, $\%$ & $0.030^{\mathrm{c}}$ & $0.031^{\mathrm{bc}}$ & $0.032^{\mathrm{ab}}$ & $0.033^{\mathrm{a}}$ & 0.001 & $<0.05$ \\
\hline $\mathrm{CN}$ to total protein, $\%$ & 78.13 & 78.67 & 78.33 & 78.80 & 0.002 & 0.25 \\
\hline $\mathrm{CN}$ to true protein, $\%$ & 83.03 & 83.20 & 83.60 & 83.40 & 0.002 & 0.32 \\
\hline Whey protein, $6 \%$ & $0.515^{\mathrm{a}}$ & $0.559^{\mathrm{a}}$ & $0.537^{\mathrm{a}}$ & $0.547^{\mathrm{a}}$ & 0.009 & $<0.05$ \\
\hline Whey protein in serum phase, ${ }^{7} \%$ & $0.542^{\mathrm{b}}$ & $0.591^{\mathrm{a}}$ & $0.568^{\mathrm{ab}}$ & $0.579^{\mathrm{ab}}$ & 0.010 & $<0.05$ \\
\hline Lactose, $\%$ & $4.61^{\mathrm{b}}$ & $4.56^{\mathrm{b}}$ & $5.02^{\mathrm{a}}$ & $5.07^{\mathrm{a}}$ & 0.037 & $<0.0001$ \\
\hline Lactose in serum phase, $8 \%$ & $4.85^{\mathrm{b}}$ & $4.83^{\mathrm{b}}$ & $5.31^{\mathrm{a}}$ & $5.36^{\mathrm{a}}$ & 0.040 & $<0.0001$ \\
\hline Total Ca, mg/100 g of milk & $112.4^{\mathrm{c}}$ & $119.2^{\mathrm{b}}$ & $120.6^{\mathrm{b}}$ & $124.2^{\mathrm{a}}$ & 0.781 & $<0.0001$ \\
\hline Total Ca, mg/g of CN & $44.70^{\mathrm{a}}$ & $43.42^{\mathrm{b}}$ & $43.91^{\mathrm{b}}$ & $45.34^{\mathrm{a}}$ & 0.235 & $<0.01$ \\
\hline $\mathrm{CN}$ :fat ratio & 1.03 & 0.99 & 0.99 & 0.99 & 0.010 & 0.18 \\
\hline \multicolumn{7}{|l|}{ Drain whey } \\
\hline TS, \% & $6.70^{\mathrm{b}}$ & $6.77^{\mathrm{b}}$ & $7.39^{\mathrm{a}}$ & $7.41^{\mathrm{a}}$ & 0.109 & $<0.001$ \\
\hline Milk fat, $\%$ & $0.27^{\mathrm{c}}$ & $0.34^{\mathrm{b}}$ & $0.37^{\mathrm{ab}}$ & $0.39^{\mathrm{a}}$ & 0.009 & $<0.0001$ \\
\hline Total protein, \% & $0.89^{\mathrm{b}}$ & $0.94^{\mathrm{a}}$ & $0.95^{\mathrm{a}}$ & $0.97^{\mathrm{a}}$ & 0.006 & $<0.001$ \\
\hline Lactose, \% & $4.87^{\mathrm{b}}$ & $4.87^{\mathrm{b}}$ & $5.35^{\mathrm{a}}$ & $5.37^{\mathrm{a}}$ & 0.052 & $<0.001$ \\
\hline \multicolumn{7}{|l|}{ Press whey } \\
\hline TS, \% & 8.68 & 8.11 & 8.38 & 9.42 & 0.515 & $\mathrm{NS}^{9}$ \\
\hline Milk fat, $\%$ & $0.12^{\mathrm{b}}$ & $0.26^{\mathrm{ab}}$ & $0.30^{\mathrm{a}}$ & $0.32^{\mathrm{a}}$ & 0.030 & $<0.01$ \\
\hline Total protein, \% & $0.62^{\mathrm{ab}}$ & $0.56^{\mathrm{b}}$ & $0.59^{\mathrm{ab}}$ & $0.68^{\mathrm{a}}$ & 0.022 & $<0.05$ \\
\hline Lactose, \% & $1.86^{\mathrm{b}}$ & $1.82^{\mathrm{b}}$ & $2.05^{\mathrm{a}}$ & $2.09^{\mathrm{a}}$ & 0.033 & $<0.001$ \\
\hline \multicolumn{7}{|l|}{ Wash water } \\
\hline TS, $\%$ & $1.09^{\mathrm{b}}$ & $1.30^{\mathrm{ab}}$ & $1.44^{\mathrm{a}}$ & $1.46^{\mathrm{a}}$ & 0.060 & $<0.05$ \\
\hline Milk fat, $\%$ & 0.071 & 0.097 & 0.129 & 0.125 & 0.016 & NS \\
\hline Total protein, $\%$ & 0.121 & 0.128 & 0.138 & 0.106 & 0.011 & NS \\
\hline Lactose, \% & $0.67^{\mathrm{b}}$ & $0.77^{\mathrm{b}}$ & $0.93^{\mathrm{a}}$ & $0.94^{\mathrm{a}}$ & 0.032 & $<0.001$ \\
\hline \multicolumn{7}{|l|}{ Cheese } \\
\hline Moisture, \% & $47.39^{\mathrm{a}}$ & $45.78^{\mathrm{b}}$ & $45.54^{\mathrm{b}}$ & $45.51^{\mathrm{b}}$ & 0.326 & $<0.05$ \\
\hline Fat, $\%$ & $22.66^{\mathrm{b}}$ & $23.69^{\mathrm{a}}$ & $23.56^{\mathrm{a}}$ & $23.34^{\mathrm{a}}$ & 0.165 & $<0.01$ \\
\hline Total protein $10 \%$ & 24.54 & 25.22 & 25.53 & 25.59 & 0.244 & NS \\
\hline Salt, \% & 1.63 & 1.81 & 1.91 & 2.05 & 0.117 & NS \\
\hline MNFS, ${ }^{11} \%$ & 61.28 & 60.00 & 59.57 & 59.33 & 0.417 & NS \\
\hline FDM ${ }^{12} \%$ & 43.07 & 43.69 & 43.26 & 42.81 & 0.363 & NS \\
\hline $\mathrm{SM}^{13} \%$ & 3.43 & 3.95 & 4.21 & 4.51 & 0.270 & NS \\
\hline Lactose at $1 \mathrm{wk}, \%$ & 0.09 & 0.17 & 0.21 & 0.28 & 0.065 & NS \\
\hline Total Ca, mg/100 g of cheese & 780 & 808 & 796 & 791 & 17.90 & NS \\
\hline Total Ca, mg/g of protein & 31.80 & 32.04 & 31.18 & 30.89 & 0.562 & NS \\
\hline $\mathrm{pH}$ at $1 \mathrm{~d}$ & 5.18 & 5.13 & 5.12 & 5.11 & 0.025 & NS \\
\hline
\end{tabular}

${ }^{a-c}$ Means within the same row not sharing a common superscript differ $(P<0.05)$.

${ }^{1}$ Means of 3 complete replicates of the treatments done on different days.

${ }^{2} \mathrm{RO}=$ reverse osmosis; EVAP = evaporation; $\mathrm{SCB}=$ sweet cream buttermilk.

${ }^{3}$ Total percentage of $\mathrm{N} \times 6.35$.

${ }^{4}($ Total $\% \mathrm{~N}-\% \mathrm{NPN}) \times 6.35$.

$5($ Total $\% \mathrm{~N}-\%$ non-CN N) $\times 6.36$.

${ }^{6}$ True protein - CN.

${ }^{7}$ Whey protein in serum phase $=$ percentage of whey protein $/(100 \%-\%$ fat $-\% \mathrm{CN})$.

${ }^{8}$ Lactose in serum phase $=$ percentage of lactose $/(100 \%-\%$ fat $-\% \mathrm{CN})$.

${ }^{9} P>0.05$.

${ }^{10}$ Total percentage of $\mathrm{N} \times 6.31$.

${ }^{11} \mathrm{MNFS}=$ moisture in the nonfat substance of the cheese.

${ }^{12} \mathrm{FDM}=$ fat content on a dry weight basis.

${ }^{13} \mathrm{SM}=$ salt in the moisture phase of the cheese. 
Cheeses were sampled after 1 wk for compositional analysis. At the time of sampling, a 1-in. (2.54-cm) slab was cut off from the block; this slab was further sampled for each analysis. The subsampled cheese sample was completely ground and used for analysis. Cheese samples were analyzed for moisture (Marshall, 1992), fat (AOAC, 2000), pH by the quinhydrone method (Marshall, 1992), protein by Kjeldahl (AOAC, 2000) using the appropriate $\mathrm{N}$ conversion factors for the different milk proteins reported by van Boekel (1993), salt by chloride electrode method (926, Corning Glass Works, Medfield, MA; Johnson and Olson, 1985), and lactose (test kit catalog number 10176303 035, R-Biopharm, Darmstadt, Germany). Proteolysis was monitored during ripening by measuring the amount of $12 \%$ TCA soluble $\mathrm{N}$ at 1,2 , and $4 \mathrm{wk}$ (AOAC, 2000).

Total $\mathrm{Ca}$ in milk and cheese was determined using a modified method of Dolan and Capar (2002). Milk $(1.0 \mathrm{~mL})$ or ground cheese $(0.4$ to $0.5 \mathrm{~g})$ samples were transferred to $55-\mathrm{mL}$ Teflon-lined heavy-duty vessels capable of operating up to $260^{\circ} \mathrm{C}$ (HP-500 vessels, CEM Corp., Matthews, NC). The milk or cheese samples were digested with $10 \mathrm{~mL}$ of $69 \%$ (wt/wt) $\mathrm{HNO}_{3}$ using a pressurized microwave wet digestion system (MARS 5 Xpress, CEM Corp.). The vessels were sealed, placed in the microwave oven, and digested by heating at $10^{\circ} \mathrm{C} /$ min to $200^{\circ} \mathrm{C}$ and holding at that temperature for 20 min. The microwave power applied was varied depending on the number of vessels in the system with 600,900 , and $1,200 \mathrm{~W}$ used for 10 to 15,16 to 25 , and 26 to 40 vessels, respectively. After completion of digestion, the vessels were cooled down, and the digested samples were transferred to test tubes. About 2 $\mathrm{mL}$ of the digest was then transferred to a $100-\mathrm{mL}$ volumetric flask and diluted to volume with deionized water.

The Ca contents of the diluted and digested samples were measured by inductively coupled Ar plasma emission spectroscopy (Vista-MPX Simultaneous ICP-OES, Varian Inc., Palo Alto, CA). Wavelength of plasma emission used to measure Ca content was $315.9 \mathrm{~nm}$.

\section{Fat and N Recovery and Yield}

A mass balance was carried out for each vat of cheese. Milk, drain whey, wash water, and press whey were weighed to $\pm 0.1 \mathrm{~kg}$, and cheese was weighed to \pm 0.01 $\mathrm{kg}$. The percentage of fat or $\mathrm{N}$ recovered in the cheese, drain whey, wash water, and press whey was calculated as the total amount of fat or $\mathrm{N}$ in each one of these products divided by the total amount of fat or $\mathrm{N}$ in the original standardized milk and multiplied by 100 .

Actual yield was calculated for each vat of cheese as the weight of the cheese divided by the weight of the original standardized milk multiplied by 100 . Actual cheese yield was also adjusted to the target cheese moisture content; for pizza cheese, this was $46 \%$. The detailed approach recently described by GovindasamyLucey et al. (2006) was used to determine the predictive cheese yield and the recoveries of fat, $\mathrm{CN}$, and other solids in cheese. Predictive cheese yields were calculated for each vat using the Van Slyke cheese yield model equation (equation [1] as shown below; Van Slyke and Price, 1936).

$$
\text { Van Slyke cheese yield }=
$$

$\frac{[(R F \times \% \text { Fat in milk })(+R C \times \% \text { CN in milk })] \times R S}{(100-\% \text { Moisture of cheese })}$

where $\boldsymbol{R F}=$ fraction of fat recovered in cheese; $\boldsymbol{R C}=$ fraction of $\mathrm{CN}$ recovered in cheese; and $\boldsymbol{R S}=$ the proportion of other milk solids and salt recovered in cheese in relation to the amount of $\mathrm{CN}$ and fat in cheese. The $R F$ values were determined experimentally as the fat recovery for each cheese type obtained during the cheese-making trials. Both $R C$ and $R S$ were calculated according to the methods described by GovindasamyLucey et al. (2006).

\section{Total PL Analysis}

The extraction of lipid was carried out using a modified Mojonnier procedure (AOAC, 2000), digestion, and subsequent spectrophotometric analysis of $\mathrm{P}$ as recently described by Govindasamy-Lucey et al. (2006). The total PL recovery in cheese was determined by subtracting the total PL found in whey, press whey, and wash water from the PL present in standardized cheesemilk.

\section{Small Amplitude Oscillatory Rheology Tests}

Rheological properties of cheeses were evaluated using a UDS 200 Physica rheometer (Physica Messtechnik, Stuttgart, Germany) as described by GovindasamyLucey et al. (2006). Cheese samples were subjected to a heating profile in the rheometer. In this test, a strain of $0.2 \%$ was applied at a frequency of $0.1 \mathrm{~Hz}$ to the cheese samples. The cheese samples were heated at a constant rate of $1^{\circ} \mathrm{C} / \mathrm{min}$ from 5 to $80^{\circ} \mathrm{C}$, and storage modulus ( $\mathbf{G}^{\prime}$; stiffness), loss modulus ( $\left.\mathbf{G}^{\prime \prime}\right)$, and loss tangent (LT) parameters were measured as a function of temperature. We also calculated the temperature where $L T=1$ (i.e., where $G^{\prime}=G^{\prime \prime}$ ), because this indicates the transition from a solid to a liquid-like system (i.e., a crossover point). 


\section{Meltprofile Analysis}

Melt-flow properties of the cheese samples were evaluated using a UW Meltprofiler as described by Muthukumarappan et al. (1999) and Govindasamy-Lucey et al. (2006). Cheese samples were sliced into discs that were $7 \mathrm{~mm}$ thick and $30 \mathrm{~mm}$ in diameter. Samples were stored in a plastic bag in the refrigerator at $6^{\circ} \mathrm{C}$ for at least $3 \mathrm{~h}$ before testing. The change in cheese height as a function of sample temperature was measured until sample temperature reached $63^{\circ} \mathrm{C}$. Degree of flow was calculated as the change in height of the cheese sample at $60^{\circ} \mathrm{C}$ as compared with the original cheese height at the beginning of the test.

\section{Sensory Analysis}

Each cheese was evaluated for bitterness, saltiness, acidity, oxidized flavor, any other off-flavors, firmness, and smoothness on a 0 to 7 point scale. Judges were trained to detect oxidized and other off-flavors by sampling oxidized milk and rancid cream samples until their scores for these attributes were consistent. Cheeses were shredded on a pilot plant scale shredder (Urschel model CC, Alard Equipment Corp., Williamson, NY). The cheeses were baked on pizza in a forcedair commercial oven (Impinger ovens, Lincoln Foodservice Products Inc., Fort Wayne, IN) at $260^{\circ} \mathrm{C}$ for $5 \mathrm{~min}$, and their performances (e.g., oiling off, strand elasticity, flow-off crust, mouthfeel, chewiness, and flavor, such as acidity and saltiness) were subjectively evaluated by a panel of 6 to 8 panelists.

\section{Experimental Design and Statistical Analysis}

Three replicate cheese-making trials were carried out; in each trial, 4 standardized milks (i.e., partskimmed milk or control, UF-SCB, RO-SCB, and EVAP$\mathrm{SCB})$ were used to make pizza cheese. A $4 \times 3$ completely randomized block design, which incorporated all 4 treatments and 3 blocks (replicate trials), was used for analysis of the response variables relating to milk, cheese, and whey composition. An ANOVA was carried out using the PROC GLM procedure of SAS (version 9.1; SAS Institute, 2003). In the ANOVA model, the 4 differently standardized milks (different treatments) were analyzed as a discontinuous variable while cheesemaking day (i.e., different batch of milk) was blocked. Scheffe's multiple-comparison test was carried out to evaluate differences in the treatment means at a significance level of $P<0.05$.

A split plot design was used to monitor the effects of treatment and time of aging and their interactions on $\mathrm{pH}$, proteolysis (12\% TCA soluble $\mathrm{N}$ expressed as a percentage of total $\mathrm{N})$, maximum $\mathrm{LT}\left(\mathbf{L} \mathbf{T}_{\max }\right)$ values, temperature of the $\mathrm{LT}_{\max }$, and temperature of crossover point and sensory performance during ripening. For the whole plot factor, treatment was analyzed as a discontinuous variable while cheese-making day was blocked. For the subplot factor analysis, age was treated as continuous variable. The interactive term treatment $x$ cheese-making day was treated as the error term for the treatment effect. An ANOVA for the split plot design was carried out using the PROC GLM procedure of SAS. Fisher's least significant difference test was carried out to evaluate differences in the treatments means at a significance level of $P<0.05$.

\section{RESULTS AND DISCUSSION}

\section{Concentrated SCB and Standardized Cheesemilk Composition}

The UF-SCB and EVAP-SCB samples had similar fat and $\mathrm{CN}$ contents; however, EVAP-SCB had more than 4 times the lactose than UF-SCB (Table 1). The solids content in EVAP-SCB was much higher than both UFand RO-SCB, because the SCB was concentrated to about $\sim 36 \%$ TS to simulate the TS levels in commercially available EVAP-SCB. The RO-SCB had the lowest fat and CN contents. Although UF-SCB and ROSCB had similar TS contents, UF-SCB had a higher $\mathrm{CN}$ content and lower lactose content than the ROSCB. Total Ca content per milligram of $\mathrm{CN}$ was similar in RO-SCB and EVAP-SCB samples but lower in UFSCB (Table 1). The amount of UF-SCB, RO-SCB, and EVAP-SCB added to the cheesemilk was approximately $3.97,8.42$, and $3.97 \%$ (weight basis, as a percentage of total cheesemilk weight), respectively (Table 2).

The TS and CN contents in the SCB standardized cheesemilks were significantly higher than the control milks (Table 3). Cheesemilks with added SCB contained $\sim 2.7 \% \mathrm{CN}$, whereas control cheesemilk contained $2.5 \%$ $\mathrm{CN}$ (Table 3). At the fortification levels used, UF-SCB, RO-SCB, and EVAP-SCB contributed 14.6, 17.4, and $13.3 \%$ of the total $\mathrm{CN}$ in the cheesemilk, respectively. Cheesemilks with added RO-SCB and EVAP-SCB contained higher lactose contents than cheesemilk with UF-SCB or control milk. All milks were standardized to a similar $\mathrm{CN}$ :fat ratio, 1.0 . The amount of total $\mathrm{Ca}$ content was higher in the SCB standardized cheesemilks than control milks, probably due to higher $\mathrm{CN}$ content in the SCB cheesemilks. Cheesemilks standardized with EVAP-SCB contained a slightly higher amount of total $\mathrm{Ca}$ than cheesemilks with added ROSCB or UF-SCB, possibly as a result of slightly higher total Ca per gram of $\mathrm{CN}$ in the EVAP-SCB concentrate (Table 1). 


\section{Cheese Composition}

When the cheeses were made from the differently concentrated SCB using the same manufacturing protocol as the control cheese, the moisture contents of the $\mathrm{SCB}$ cheeses were similar (UF-SCB $=51.7 \%$; RO-SCB $=$ $51.8 \%$; EVAP-SCB $=52.4 \%$ ) but were $\sim 4$ to $5 \%$ higher than control cheeses (47.2\%; results not shown). All 3 SCB cheeses had a lower $\mathrm{pH}$ than control (4.87 to 4.99), a soft body, did not shred well, and had poor stretch when baked on pizzas. Without adjusting the cheesemaking procedure, the addition of concentrated SCB increased the moisture of cheese by more than $4 \%$. This agrees with previous studies that have shown that addition of buttermilk increased the moisture content of reduced-fat cheese (Madsen et al., 1966; Joshi and Thakar, 1993; Mayes et al., 1994; Mistry et al., 1996) and pizza cheese (Govindasamy-Lucey et al., 2006). This increase in moisture with addition of SCB could be due to the presence of denatured whey proteins, because SCB had been subjected to several heat treatments (Govindasamy-Lucey et al., 2006). Whey protein denaturation in pasteurized cream obtained from a local dairy, measured over 1-yr period has been found to range from 18 to 59\% (Govindasamy-Lucey et al., 2006). The unconcentrated SCB used in the present study was also obtained from the same local dairy. These denatured whey proteins can form cross-links with $\mathrm{CN}$ micelles and disrupt the structure of the rennet-induced milk gel and reduce the extent of syneresis of the gel, which can increase the moisture content of cheese (Lawrence, 1987; Leaver et al., 1995; Mead and Roupas, 2001). However, there were no significant differences in the CN:true protein ratio in our cheesemilk samples (Table 3), suggesting that it could be something other than denatured whey proteins that was responsible for the impairment of syneresis (e.g., the PL present in SCB).

When the manufacturing protocol was modified for the SCB cheeses by increasing the set temperature (from 34.4 to $35.6^{\circ} \mathrm{C}$ ), cook temperature (from 36.7 to $38.9^{\circ} \mathrm{C}$ ), and wash temperature (from 23.9 to $32.2^{\circ} \mathrm{C}$ ) for the SCB cheeses, the moisture content of all 3 SCB cheeses was slightly lower than the control cheeses but within the range that is expected for this cheese type, $\sim 46$ to $47 \%$ (Table 3). Cheeses with added SCB also underwent a longer stirring time after the curd was drained. This stirring step also helped to remove more moisture from curd before the curd was pressed. All compositional and functional data reported in this paper are from the moisture-adjusted SCB trials.

All 3 SCB cheeses had significantly $(P<0.05)$ lower moisture content than the control, which resulted in SCB-fortified cheese having slightly higher fat contents than the control, but the fat contents of the cheeses on a dry weight basis were not significantly different and within the typical range of values $(43 \%)$ for this stirred-curd pizza cheese (Table 3). Cheeses made with added concentrated SCB also had similar protein contents. Salt contents of the SCB cheeses were slightly higher than the control cheeses, although not significantly different. The lactose content of all cheeses after 1 wk was low ( 0.09 to $0.28 \%$ ) and not significantly different among treatments. There was no significant difference among the total $\mathrm{Ca}$ content in the 4 treatments. Overall, cheeses made with concentrated SCB had similar composition to the control cheeses.

\section{Fat, N, and PL Recovery}

Fat recovery in the control and UF-SCB cheeses was significantly higher than in the RO-SCB or EVAP-SCB cheeses (Table 4), which was also reflected in the significantly lower fat losses in the drain whey of the control and UF-SCB cheeses.

The amounts of $\mathrm{N}$ recovered in the control, UF-SCB, RO-SCB, and EVAP-SCB cheeses were $73.41 \pm 1.14$, $75.33 \pm 0.51,74.40 \pm 0.64$, and $74.72 \pm 1.49 \%$, respectively. Although there were no statistically significant differences in the amount of $\mathrm{N}$ recovered in all the cheeses, $\mathrm{N}$ recoveries in cheeses made with control milks were slightly lower than the cheeses made with SCB milks (Table 4). The N recovery in the control cheeses as well as the SCB-fortified cheese showed considerable variation. This was possibly due to seasonal changes in the proportions of individual $\mathrm{CN}$ or variation in rennet coagulation properties. More $\mathrm{CN}$ and/or less NPN would result in an increase in $\mathrm{N}$ recovery. Variation in the amount of $\mathrm{N}$ recovered in the SCB-fortified cheeses could be due to variation in the amount of denatured whey protein in the unconcentrated SCB. Whey protein denaturation in pasteurized cream obtained from this same local creamery has been shown to vary substantially over a 1-yr period (Govindasamy-Lucey et al., 2006). These variations could affect the amount of denatured whey proteins found in unconcentrated SCB produced from the butter-making process. Previous work has demonstrated that a higher amount of $\mathrm{N}$ was recovered in pizza cheeses made from cheesemilks standardized using 4 or $6 \%$ of commercially EVAP-SCB than control or $2 \%$ EVAP-SCB-fortified cheeses (Govindasamy-Lucey et al., 2006). Mistry et al. (1996) also reported slightly higher (but not significant) protein recovery in reduced-fat Cheddar cheese made from milk fortified with 5\% UF-SCB.

The total amount of PL recovery in SCB-fortified cheese was lower than the control cheese due to the majority of the additional PL from SCB being lost in 
Table 4. Fat, N, and phospholipids recovery ${ }^{1}$ for pizza cheeses made using the modified manufacturing protocol to adjust the moisture contents of the sweet cream buttermilk (SCB) cheeses

\begin{tabular}{lcccccc}
\hline & \multicolumn{7}{c}{ Treatment $^{2}$} & & \\
\cline { 2 - 5 } Component recovery & Control & UF-SCB & RO-SCB & EVAP-SCB & SEM & $P$-value \\
\hline Fat recovery, ${ }^{3} \%$ & & & & & & \\
$\quad$ Cheese & $88.37^{\mathrm{a}}$ & $87.99^{\mathrm{a}}$ & $86.26^{\mathrm{b}}$ & $85.78^{\mathrm{b}}$ & 0.291 & $<0.001$ \\
Drain whey & $9.57^{\mathrm{c}}$ & $10.59^{\mathrm{b}}$ & $11.60^{\mathrm{a}}$ & $12.08^{\mathrm{a}}$ & 0.226 & $<0.0001$ \\
Pressed whey & 0.090 & 0.207 & 0.240 & 0.153 & 0.038 & 0.103 \\
Wash water & 0.437 & 0.590 & 0.823 & 0.767 & 0.112 & NS \\
Total & 98.47 & 99.40 & 98.81 & 98.78 & & \\
Nitrogen recovery, ${ }^{3} \%$ & & & & & & \\
Cheese & 73.41 & 75.33 & 74.40 & 74.72 & 0.629 & NS \\
Drain whey & $24.43^{\mathrm{a}}$ & $23.09^{\mathrm{b}}$ & $23.45^{\mathrm{ab}}$ & $23.89^{\mathrm{ab}}$ & 0.217 & $<0.01$ \\
Pressed whey & 0.327 & 0.328 & 0.340 & 0.270 & 0.020 & NS \\
Wash water & 0.582 & 0.661 & 0.698 & 0.739 & 0.035 & NS \\
$\quad$ Total & 98.75 & 99.41 & 98.88 & 99.62 & & \\
Drain whey, ${ }^{4} \%$ & $75.92^{\mathrm{a}}$ & $72.42^{\mathrm{b}}$ & $73.12^{\mathrm{b}}$ & $73.38^{\mathrm{b}}$ & 0.504 & $<0.01$ \\
Pressed whey ${ }^{4} \%$ & 1.88 & 2.10 & 2.13 & 1.50 & 0.188 & NS \\
Wash water, ${ }^{4} \%$ & $13.43^{\mathrm{c}}$ & $15.06^{\mathrm{b}}$ & $15.28^{\mathrm{b}}$ & $15.78^{\mathrm{a}}$ & 0.141 & $<0.0001$ \\
Phospholipid recovery in cheese, $\%$ & $40.67^{\mathrm{a}}$ & $36.55^{\mathrm{b}}$ & $33.98^{\mathrm{c}}$ & $32.57^{\mathrm{d}}$ & 0.388 & $<0.0001$ \\
\hline
\end{tabular}

${ }^{\mathrm{a}-\mathrm{d}}$ Means within the same row not sharing a common superscript differ $(P<0.05)$.

${ }^{1}$ Means of 3 complete replicates of the treatments done on different days.

${ }^{2} \mathrm{RO}=$ reverse osmosis; EVAP = evaporation.

${ }^{3}$ The percentage of fat or $\mathrm{N}$ recovered in the cheese, drain whey, wash water, and press whey was calculated as the total amount of fat or $\mathrm{N}$ in each one of these products divided by the total amount of fat or $\mathrm{N}$ in the original standardized milk multiplied by 100 .

${ }^{4}$ Amount of drain whey, press whey, and wash water obtained from $100 \mathrm{~kg}$ of cheesemilk.

whey (Table 4). Polar lipids (e.g., sphingolipids) are preferentially enriched in buttermilk (Rombaut et al., 2006). Presumably, a considerable proportion of the polar lipids from SCB are present in the serum-whey phase of cheesemilks that are made with added SCB, and most of these polar lipids would be presumably lost along with the whey during cheese making. The lower PL recovery may have been due to the origin and type of the PL in SCB. Previous work by Lin (2003) had shown that when pasteurized milk (2.3\% fat) was ultracentrifuged for $100,000 \times g$ for $50 \mathrm{~min}$ at $15^{\circ} \mathrm{C}$, the individual layers, lipid, supernatant (serum phase), and pellet (CN phase), contained about 42,46 , and $14 \%$ of the total PL found in milk, respectively. Because more than $40 \%$ of the PL in milk are found in the serum phase, a substantial amount of PL would likely be lost in the whey during cheese making (Lin, 2003). Phospholipids that were associated with $\mathrm{CN}$ and with large membrane materials could potentially be retained in the curd matrix. Physical agitation, such as cutting and stirring of cheese curd, as well as the washing step, could further reduce the amount of PL recovered in the cheese matrix. The PL in SCB were from both the disrupted MFGM materials and PL present in milk serum phase. It was uncertain how much of the PL from SCB was recovered in the cheese (because there were also PL derived from milk).

It was unclear as to why the PL recovery in the 3 SCB cheeses was different. One possible explanation could be that the different concentrating processes of SCB might alter the PL species and modify its location in the different phases of SCB. Residual whey fat, including PL, has been associated with fouling of UF membranes (Rombaut et al., 2006). This indicates that at least part of the polar lipids (mainly PL) is concentrated during UF. In the case of EVAP-SCB cheese, the heat treatment during the concentration process (64 to $65^{\circ} \mathrm{C}$ for $\sim 5 \mathrm{~h}$ ) may have degraded some PL. Lin (2003) showed that after heat treatment, some of the PL from the raw cream were lost, and $~ 89 \%$ of PL were retained in the pasteurized cream, suggesting that the heating process degraded the PL. This degradation could result in the conversion of PL to lysophospholipids as suggested by Nakanishi and Kaya (1970). According to Nakanishi and Kaya (1970), after heating the milk for $63^{\circ} \mathrm{C}$ for $30 \mathrm{~min}$, about $96 \%$ of the original PL were retained in the pasteurized milk. When the cream was pasteurized, the concentration of phosphatidylethanolamine (PE) decreased, whereas the concentration of phosphatidylcholine (PC) and sphingomyelin (SP) appeared to increase (Lin, 2003). One possible explanation could be that PE was more heat sensitive than PC and SP. This result agreed with the findings by Nakanishi and Kaya (1970) and Sharma et al. (1994), which showed that concentration of $\mathrm{PE}$ was relatively lower than PC in heat-treated milk. Rombaut et al. (2006) showed that the concentrations of $\mathrm{PE}$, phosphatidylserine, and phosphatidylinositol were significantly and 
Table 5. Actual and calculated cheese yield values for pizza cheese ${ }^{1}$ made using the modified manufacturing protocol to adjust for the moisture in the sweet cream buttermilk (SCB) cheeses

\begin{tabular}{|c|c|c|c|c|}
\hline \multirow[b]{2}{*}{ Item } & \multicolumn{4}{|c|}{ Treatment $^{2}$} \\
\hline & Control & UF-SCB & RO-SCB & EVAP-SCB \\
\hline$R F$ value $^{3}$ & 0.884 & 0.880 & 0.863 & 0.858 \\
\hline$R S$ value $^{4}$ & 1.115 & 1.109 & 1.110 & 1.114 \\
\hline$R C$ value $^{5}$ & 0.934 & 0.951 & 0.939 & 0.949 \\
\hline Actual yield, ${ }^{6} \%$ & 9.56 & 10.35 & 10.11 & 10.16 \\
\hline Van Slyke cheese yield ${ }^{7} \%$ using $R F, R C$, and $R S$ values & 9.56 & 10.35 & 10.11 & 10.16 \\
\hline Averaged moisture adjusted yield to $46 \%$ moisture, $\%$ & 9.32 & 10.39 & 10.19 & 10.25 \\
\hline $\begin{array}{l}{ }^{1} \text { Means of } 3 \text { complete replicates of the treatments done } \\
{ }^{2} \mathrm{RO}=\text { reverse osmosis; EVAP }=\text { evaporation. } \\
{ }^{3} R F=\text { the fat recovered in cheese, determined experimer } \\
{ }^{4} R S=\text { the recovery of non-CN nonfat solids in cheese. I }\end{array}$ & $\begin{array}{l}\text { tally from } \\
\text { was calcu }\end{array}$ & $\begin{array}{l}\text { days. } \\
\text { heese trial } \\
\text { ated as de }\end{array}$ & cribed in $\mathrm{G}$ & vindasamy- \\
\hline \multicolumn{5}{|c|}{$\begin{array}{l}{ }^{5} R C \text { = fraction of } \mathrm{CN} \text { recovered in cheese. It was calculated as described in Govindasamy-Lucey et al. } \\
(2006) \text {. }\end{array}$} \\
\hline \multicolumn{5}{|c|}{$\begin{array}{l}{ }^{6} \text { Actual yield was calculated as the weight of the cheese divided by the weight of the original standardized } \\
\text { milk multiplied by } 100 \text {. }\end{array}$} \\
\hline
\end{tabular}

negatively correlated with the PC and SP content. The authors attributed this relationship among the different PL to the specific location of the polar lipids in the MFGM; SP and PC are found on the outside of the MFGM, whereas PE, phosphatidylserine, and phosphatidylinositol are found on the inner surface of MFGM (Deeth, 1997; Danthine et al., 2000).

\section{Cheese Yield}

Actual and moisture-adjusted yields in the SCB-fortified cheeses increased (Table 5) due to the higher CN and fat content in the SCB-standardized milks. Van Slyke cheese yield equations were developed by the procedure described by Govindasamy-Lucey et al. (2006) for the control and SCB cheeses (Table 5). The calculated $R C$ values for control, UF-, RO- and EVAPSCB cheeses were $0.934,0.951,0.939$ and 0.949 , respectively. The calculated $R C$ values tended to be slightly higher for SCB cheeses compared with the control cheeses and followed the trend for the total $\mathrm{N}$ recovered in cheese (Table 4). This trend is in agreement with our previous work that found that when different concentrations $(2,4$, and $6 \%$ ) of commercial EVAP-SCB were added to cheesemilks used in the manufacture of pizza cheese, the calculated $R C$ values increased with increasing amount of SCB used (Govindasamy-Lucey et al., 2006). This is possibly due to some additional denatured whey proteins associated with $\mathrm{CN}$ that were recovered along with $\mathrm{CN}$ in this cheese. However, there were no significant differences in the $\mathrm{CN}$ to true protein ratio in our SCB samples (Table 3), suggesting that it could be something other than denatured whey proteins that was responsible for the increase in RC for SCBfortified cheeses (e.g., altered coagulation properties causing a reduction in the amount of curd fines). All calculations ( $R F, R S$, and Van Slyke cheese yield) were carried out using the individual calculated $R C$ values for each cheese type (Table 5). By using the calculated $R C$ values and the experimentally determined $R F$ values (from this yield study), $R S$ was calculated. The Van Slyke cheese yield formula correctly predicted the experimentally obtained actual cheese yield (Table 5).

\section{Whey Composition}

There was a slight (but not statistically significant) reduction in the total amount of whey produced (including drain whey, press whey, and wash water) during cheese making in the cheesemilks standardized with SCB compared with control milks (Table 6). Lactose levels were significantly $(P<0.01)$ higher in the whey derived from milks standardized with RO- and EVAPSCB than the control or UF-SCB wheys. This was expected, because the lactose contents in the RO- and EVAP-SCB standardized milks were higher than the control or UF-SCB milks (Table 3). True protein contents were similar in the wheys produced from the SCBstandardized milks but higher than control (Table 6). The fat content of whey obtained from the SCB cheesemilks was higher than the control whey. The proportion of lactose in the TS of whey produced from all 4 milks was similar. True protein levels as a percentage of TS were higher in the wheys produced from the UF-SCB milks $(10.3 \%)$ than the control $(9.7 \%)$ or RO- $(9.3 \%)$ or EVAP-SCB (9.3\%) milks. This is in agreement with 
Table 6. Mean ${ }^{1}$ total whey, lactose, true protein, TS, and total fat composition in whey, normalized to concentrations that would be produced from $100 \mathrm{~kg}$ of standardized milk made using the modified cheese manufacturing protocol to adjust for the moisture in the sweet cream buttermilk (SCB) cheeses

\begin{tabular}{|c|c|c|c|c|c|c|c|}
\hline \multirow[b]{2}{*}{ Treatments $^{2}$} & \multicolumn{7}{|c|}{ Total amount in cheese whey } \\
\hline & $\begin{array}{l}\text { Total } \\
\text { whey, } \\
\text { kg }\end{array}$ & $\begin{array}{c}\text { Lactose, } \\
\text { kg }\end{array}$ & $\begin{array}{l}\text { True } \\
\text { protein, } \\
\text { kg }\end{array}$ & $\begin{array}{l}\mathrm{TS}, \\
\mathrm{kg}\end{array}$ & $\begin{array}{c}\text { Total } \\
\text { fat, kg }\end{array}$ & $\frac{\text { Lactose }}{\mathrm{TS}, \%}$ & $\frac{\text { True protein }}{\mathrm{TS}, \%}$ \\
\hline Control & 91.22 & $3.82^{\mathrm{b}}$ & $0.523^{\mathrm{b}}$ & $5.40^{\mathrm{b}}$ & $0.214^{\mathrm{c}}$ & 70.84 & $9.70^{\mathrm{b}}$ \\
\hline UF-SCB & 89.59 & $3.68^{\mathrm{b}}$ & $0.540^{\mathrm{a}}$ & $5.27^{\mathrm{b}}$ & $0.269^{b}$ & 69.95 & $10.25^{\mathrm{a}}$ \\
\hline RO-SCB & 90.53 & $4.10^{\mathrm{a}}$ & $0.541^{\mathrm{a}}$ & $5.80^{\mathrm{a}}$ & $0.298^{\mathrm{ba}}$ & 70.68 & $9.34^{\mathrm{b}}$ \\
\hline EVAP-SCB & 90.66 & $4.12^{\mathrm{a}}$ & $0.541^{\mathrm{a}}$ & $5.80^{\mathrm{a}}$ & $0.308^{\mathrm{a}}$ & 70.98 & $9.32^{\mathrm{b}}$ \\
\hline SEM & 0.447 & 0.041 & 0.004 & 0.093 & 0.007 & 1.571 & 0.212 \\
\hline$P$-value & NS & $P<0.01$ & $P<0.01$ & $P<0.01$ & $P<0.01$ & NS & $P<0.05$ \\
\hline
\end{tabular}

${ }^{\mathrm{a}-\mathrm{c}}$ Means within the same column not sharing a common superscript differ $(P<0.05)$.

${ }^{1}$ Means of 3 complete replicates of the treatments done on different days.

${ }^{2} \mathrm{RO}=$ reverse osmosis; EVAP = evaporation.

${ }^{3}$ Total whey $=$ drain whey + press whey + wash water.

previous work, in which true protein levels as a percentage of TS were higher in the whey produced from milks standardized with UF retentates than control milks (Govindasamy-Lucey et al., 2005).

\section{$\mathrm{pH}$ and Proteolysis}

Both $\mathrm{pH}$ and the amount of $12 \%$ TCA soluble $\mathrm{N}$ formed during ripening were similar among all the treatments (Table 7). The $\mathrm{pH}$ of all cheese hardly changed during ripening (results not shown). Only about $<0.3 \%$ of the lactose remained in cheese after wk 1 (Table 3), which indicated that most of the lactose was rapidly utilized. The washing step in pizza cheese manufacture helped to remove most of the residual lactose. As expected, the amount of $12 \%$ TCA soluble N increased with ripening (Table 7). Based on our previous work (Govindasamy-Lucey et al., 2005), both starter:CN and rennet:CN ratios were kept the same for both the control and experimental vats. As a result, there was no difference in the amount of $12 \%$ TCA soluble $\mathrm{N}$ formed in the cheeses during ripening (Table 7).

\section{Rheological Properties}

The $G^{\prime}$ values for the control cheeses decreased as temperature was increased from 5 to $80^{\circ} \mathrm{C}$ (Figure 1, panel A), in agreement with other studies (Rosenberg et al., 1995; Lucey et al., 2003). As the control cheeses aged, the $\mathrm{G}^{\prime}$ values at $\leq 30^{\circ} \mathrm{C}$ did not appear to be very different. However, as the temperature was increased from 30 to $80^{\circ} \mathrm{C}$, the $\mathrm{G}^{\prime}$ values of cheeses of various ages became distinctly different (Figure 1, panel A), with lower $G^{\prime}$ values for 4 -wk-old cheeses. Similar trends were also seen for the $G^{\prime}$ as a function of temperature for the other cheese types (results not shown).
The LT values of control cheese at temperatures $\leq 30^{\circ} \mathrm{C}$ remained constant during ripening (Figure 1, panel B) with a value of $\sim 0.3$; the $\mathrm{LT}$ increased at $\geq 30^{\circ} \mathrm{C}$ to a maximum at $\sim 60$ to $65^{\circ} \mathrm{C}$ and then decreased. An increase in LT indicates a change in the character of the cheese from solid-like to viscous or liquid-like character. The LT value (at temperatures $>30^{\circ} \mathrm{C}$ ) of the cheese increased with age of cheese (Figure 1, panel B). Similar LT as a function of temperature profiles were observed for the SCB cheeses (results not shown).

The value for the LT peak (maximum) for all cheeses increased as the cheese aged up to $\sim 4$ wk (Figure 2). The age-related increase in LT and decrease in $\mathrm{G}^{\prime}$ at high temperatures is presumably due to a decrease in the amount of insoluble $\mathrm{Ca}$ associated with $\mathrm{CN}$ particles (increase in serum Ca) as well as proteolysis (Lucey et al., 2003). The LT value at higher temperature has been used as an index of meltability (Mounsey and O'Riordan, 1999). A high LT indicates a more liquid-like system, which could then soften and flow. Control cheeses had significantly higher $\mathrm{LT}_{\max }$ values at all time points compared with cheeses from SCB treatments (Table 7, Figure 2). All of the $3 \mathrm{SCB}$ cheeses had similar $\mathrm{LT}_{\max }$ values throughout the ripening period (Figure 2).

The temperature at which the $\mathrm{LT}_{\max }$ occurred was not affected by treatment (Table 7); however, there were some differences among treatments with age, as indicated by the statistical significance of the age $\times$ treatment term. At 1 wk of storage, the $\mathrm{LT}_{\max }$ occurred at a slightly lower temperature $\left(66\right.$ to $\left.67^{\circ} \mathrm{C}\right)$ for the SCB cheeses than the control cheeses $\left(\sim 68^{\circ} \mathrm{C}\right.$; Figure 3$)$. After 2 wk of storage, the $\mathrm{LT}_{\max }$ temperature was similar for control, UF-SCB, and EVAP-SCB cheeses but lower than the RO-SCB cheeses. By 4 wk of storage, the $\mathrm{LT}_{\max }$ temperature was lower for the control cheese compared with SCB cheeses. The temperature at which 

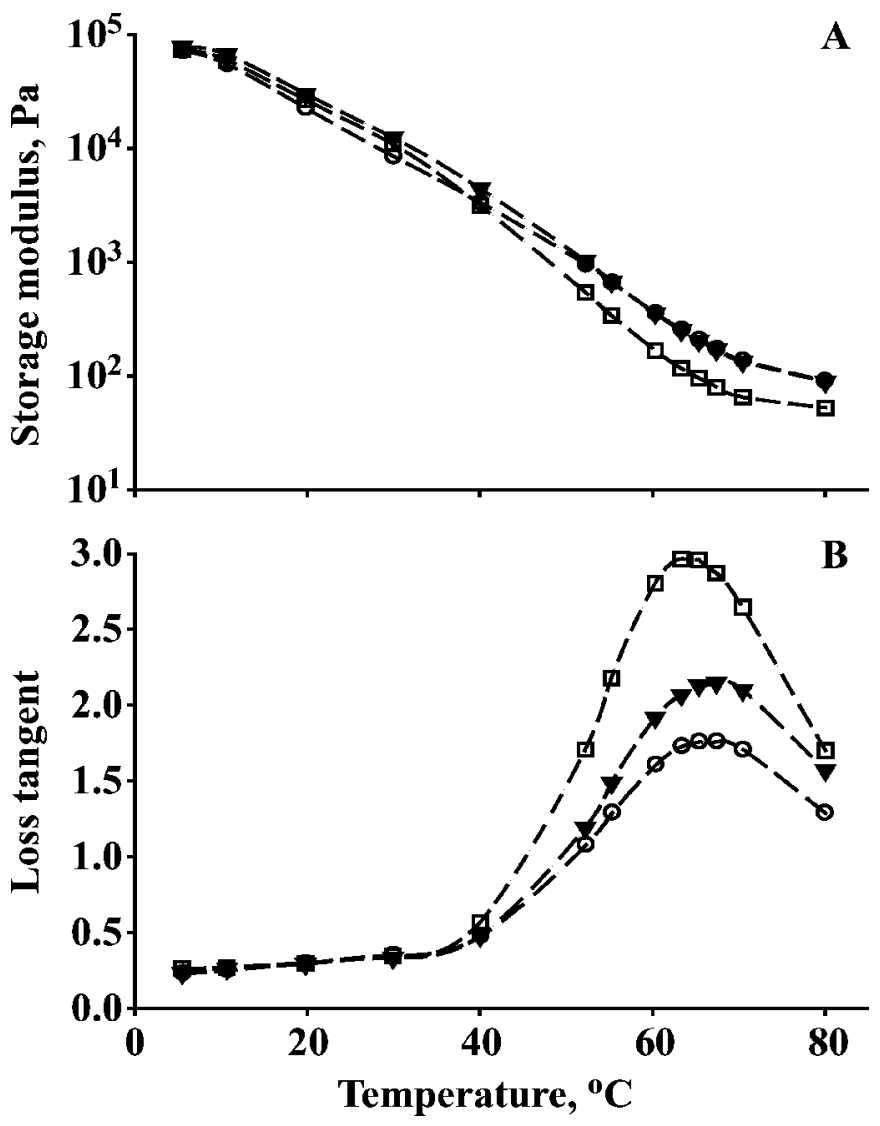

Figure 1. Changes in the (A) storage modulus $\left(G^{\prime}\right)$ and (B) loss tangent as a function of temperature from the dynamic low-amplitude oscillatory rheology for the control pizza cheeses at $1(\bigcirc), 2(\boldsymbol{\nabla})$, and $4(\square)$ wk of ripening at $7^{\circ} \mathrm{C}$.

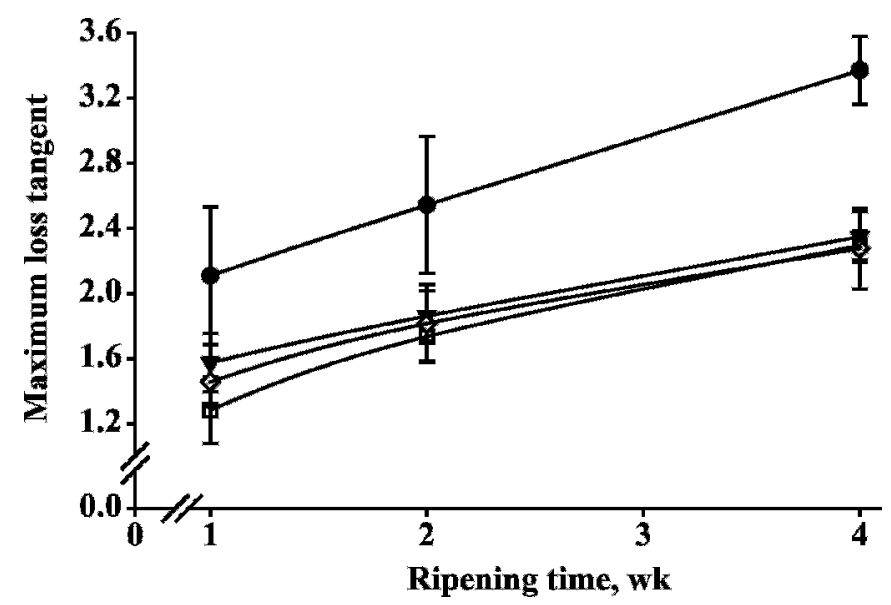

Figure 2. Changes in the maximum loss tangent from the dynamic low-amplitude oscillatory rheology test for the control (๑), UF-SCB $(\nabla)$, RO-SCB $(\square)$, and EVAP-SCB $(\diamond)$ during the 4 wk of ripening pizza cheeses at $7^{\circ} \mathrm{C}$. Vertical bars represent standard deviations. $\mathrm{RO}=$ reverse osmosis; $\mathrm{EVAP}$ = evaporation; $\mathrm{SCB}=$ sweet cream buttermilk. 


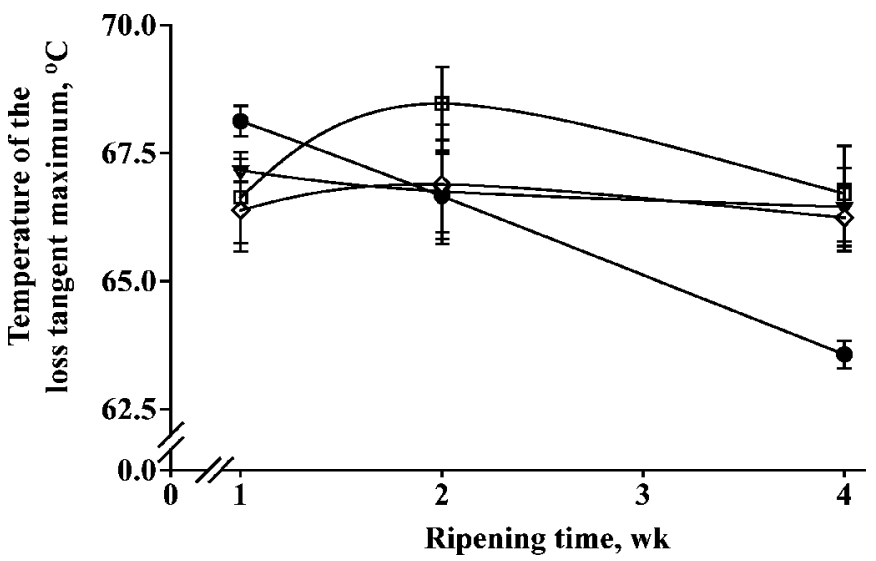

Figure 3. Changes in the temperature of the loss tangent maximum from the dynamic low-amplitude oscillatory test for the control $(\bullet), \mathrm{UF}-\mathrm{SCB}(\boldsymbol{\nabla}), \mathrm{RO}-\mathrm{SCB}(\square)$, and EVAP-SCB $(\diamond)$ during the 4 wk of ripening of pizza cheeses at $7^{\circ} \mathrm{C}$. Vertical bars represent standard deviations. $\mathrm{RO}=$ reverse osmosis; $\mathrm{EVAP}=$ evaporation; $\mathrm{SCB}=$ sweet cream buttermilk.

the $\mathrm{LT}_{\max }$ occurred decreased as a function of age (Figure 3). However, for the SCB cheeses, there was no change in the $\mathrm{LT}_{\max }$ temperature with age except for the RO-SCB cheeses, in which the temperature slightly increased from 1 to $2 \mathrm{wk}$ of age and then decreased again in cheese at the 4 -wk ripening point. The crossover point (i.e., when LT $=1$ ) has been used as another indicator of cheese meltability (Sutheerawattanonda and Bastian, 1998). There was no significant difference in the temperature of this crossover for any of the 4 cheese types (Table 7).

Melting properties of cheese are determined primarily by the number and strength of $\mathrm{CN}-\mathrm{CN}$ interactions (Lucey et al., 2003). The significantly higher $\mathrm{LT}_{\max }$ values for the control cheese compared with SCB standardized cheese could be due to the significantly higher moisture content in control cheese. It is also well known that denatured whey proteins reduce cheese meltability, and the addition of UF-SCB, RO-SCB, and EVAPSCB probably introduced some denatured whey proteins into the system. Another possible reason for the lower $\mathrm{LT}_{\max }$ in SCB cheese could be that the addition of PL in SCB-fortified cheeses hindered meltability.

\section{UW Meltprofiler}

The meltability of cheese was compared by using the parameter "degree of flow," which was the percentage of change in the height of cheese when it was heated to $60^{\circ} \mathrm{C}$ compared with the original cheese height. Degree of flow in all the cheeses was not significantly different (Table 7), although control cheese had slightly higher flow at each point compared with the SCB

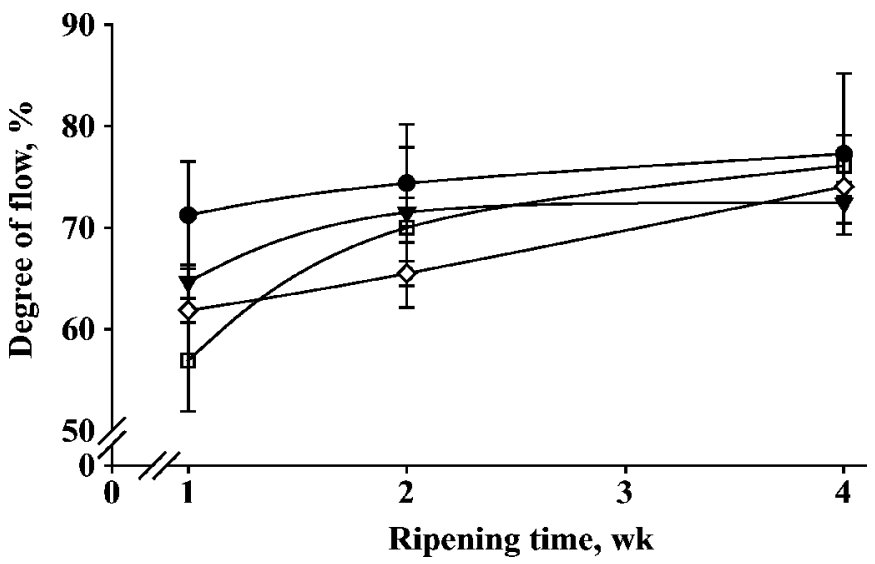

Figure 4. Age-related changes in the degree of flow calculated from the UW Meltprofiler for the control ( ), UF-SCB $(\boldsymbol{\nabla})$, RO-SCB $(\square)$, and EVAP-SCB $(\diamond)$ cheeses made with differently processed sweet cream buttermilk (SCB) during the 4 wk of ripening of pizza cheeses at $7^{\circ} \mathrm{C}$. Vertical bars represent standard deviations. $\mathrm{RO}=$ reverse osmosis; EVAP = evaporation.

cheeses (Figure 4). As the cheeses ripened, their degree of flow increased in all treatments (Figure 4, Table 7).

\section{Sensory Attributes}

There were no differences in the following unmelted cheese attributes in cheese made with and without added SCB (results not shown): bitterness, saltiness, acidity, firmness, and smoothness. There was only slight bitterness ( 0.1 to 0.4 ) or oxidized flavors ( 0.2 to 0.5 ) detected by the judges at any point in cheese that was melted on pizza in an Impinger oven and no difference in oxidized flavor among treatments (Table 8). The acidic taste of the melted cheeses was similar among all treatments at all time points. Although the amount of free oil observed on the surface of the pizzas was not significantly affected by treatment (Table 8), it was slightly lower for cheeses made with added SCB (1.0 to 1.5) compared with control cheese (2.0 to 3.1). Cheeses with UF-SCB tended to have the lowest score for the amount of free oil observed on the surface of the pizzas. The amount of free oil on the surface of pizza did not change much during ripening. All 4 cheese types had similar degrees of chewiness (Table 8).

Immediately after melting, cheese was tested for stretchability by lifting a piece of cheese using a fork and pulling the cheese until the strands broke. Treatment did affect the strand length significantly $(P<$ $0.05)$; control cheeses had the longest strand length compared with other SCB cheeses (Table 8). At $1 \mathrm{wk}$, strand lengths for the control, UF-SCB, RO-SCB, and EVAP-SCB cheeses were $\sim 13,7,7$, and $9 \mathrm{~cm}$, respectively. The strand length for the SCB cheeses was simi- 
Table 8. Mean squares, probabilities (in parentheses), and $\mathrm{R}^{2}$ for sensorial properties of the cheeses made with differently processed sweet cream buttermilk (SCB) using the modified manufacturing protocol, melted on pizzas in a forced-air commercial oven ${ }^{1}$ during the 4 wk ripening

\begin{tabular}{lccclc}
\hline Item & df & Free oil & Strand length & \multicolumn{1}{c}{ Chewiness } & Oxidized flavor $^{3}$ \\
\hline Whole plot & & & & & \\
Treatment & 3 & $5.85(0.37)$ & $108.18^{*}(<0.05)$ & $0.126(0.55)$ & $0.05(0.65)$ \\
Day of cheese making (D) & 1 & $9.19(0.22)$ & $325.5^{*}(<0.05)$ & $5.89^{* *}(<0.01)$ & $0.36(0.12)$ \\
Error (T $\times$ D) & 3 & 3.82 & 6.78 & 0.179 & 0.09 \\
Subplot & & & & & \\
Age (A) & 2 & $0.203(0.70)$ & $32.04(0.09)$ & $0.56^{*}(<0.05)$ & $0.06(0.56)$ \\
A $\times$ T & 6 & $0.571(0.44)$ & $6.80(0.76)$ & $0.15(0.57)$ & $0.10(0.39)$ \\
Error & 32 & 0.323 & 12.16 & 0.18 & 0.25 \\
$\mathrm{R}^{2}$ & & 0.70 & 0.67 & 0.60 & 0.68 \\
\hline
\end{tabular}

${ }^{1}$ Impinger ovens, Lincoln Foodservice Products Inc. (Fort Wayne, IN).

${ }^{2}$ Strand length was measured as inches by the fork test; not based on a 0 - to 7-point scale.

${ }^{3}$ Oxidized flavor of the unmelted cheese chunks.

$* P \leq 0.05 ; * * P \leq 0.01$.

lar at all time points. Stretchability of cheeses with added SCB might have been impaired due to likely introduction of the denatured serum proteins in SCB. Stretch is the ability of the CN network to stay intact when a continuous stress is applied to the cheese (Lucey et al., 2003). Cross-links between denatured serum proteins and $\mathrm{CN}$ tend to interrupt $\mathrm{CN}-\mathrm{CN}$ interactions (Lawrence, 1987). During stretching, CN molecules that have denatured whey proteins attached would not readily slide past other $\mathrm{CN}$ due to the presence of disulfide bonds that would resist stretching (because these covalent bonds are not as mobile as other types of bonds).

\section{CONCLUSIONS}

Addition of UF-, RO-, and EVAP-SCB to standardize milks for pizza cheese manufacture increased cheese yield due to higher $\mathrm{CN}$ and fat contents. Without modifications in cheese manufacturing protocol, SCB-fortified cheeses were very soft due to an increase in the moisture content and were not suitable for pizza applications (e.g., they exhibited poor shredding). It was necessary to adjust the cheese-making procedures for SCBfortified cheeses to obtain similar moisture contents to the control. The total PL (from the part-skimmed milk and added SCB) recovery was lower for cheeses from SCB treatments, which indicated that most PL were not retained in the cheese during manufacturing, regardless of how SCB was concentrated. A possible reason is most of the PL in SCB are polar lipids that are soluble in the serum phase and are likely to be lost in whey during cheese making. Cheeses made with added SCB had slightly lower meltability (as indicated by the slightly lowered $\mathrm{LT}_{\max }$ and degree of flow values) and stretchability than control cheeses. The flavor attributes of the 4 treatments were similar, which indicated that addition of SCB did not significantly alter cheese flavor. Free oil on pizzas was slightly lower in SCBfortified cheeses. It appeared that all types of concentrated SCB performed reasonably well in pizza cheese applications. Overall, the addition of concentrated SCB to cheesemilk could improve the cheese yield and lower free oil on the surface of the melted cheese without adversely affecting the functional properties of pizza cheese. Pizza cheese has low free oil levels, so the importance in reducing free oil may be more obvious in pasta filata-type cheeses. The use of UF for concentrating SCB is attractive, because the UF concentrates that are produced have high $\mathrm{CN}$, low lactose contents, and have the highest PL recovery during cheese making compared with RO- or EVAP-SCB. Additional studies that we have conducted (results not shown) have demonstrated that SCB can also be used for standardizing cheesemilks in the manufacture of high-moisture cheeses, such as feta and ricotta, in which the amount whey protein denaturation or the high lactose contents in EVAP-SCB or RO-SCB does not have any negative effect on the quality of these cheeses.

\section{ACKNOWLEDGMENTS}

We thank the following Wisconsin Center for Dairy Research and University of Wisconsin dairy plant personnel for their assistance and support in cheese-making and analytical work: Bill Hoesly, Brian Leitzke, Bill Tricomi, Amy Bostley, Kristen Houck, Cathy Landers, Juan Romero, Gene Barmore, Karen Smith, Ray Michaels, Ken Norton, Gina Mode, and Bill Klein. We also thank Jongwoo Choi for his help with the statistical analysis of the data. We also thank Chr. Hansen Inc. (Milwaukee, WI) and Danisco USA (Madison, WI) for their donation of starter cultures and coagulants used in this study. The financial support of the Dairy Man- 
agement Inc. (Rosemont, IL) and Wisconsin Milk Marketing Board (Madison, WI) is greatly appreciated.

\section{REFERENCES}

AOAC. 2000. Official Methods of Analysis. 17th ed. AOAC, Arlington, VA.

Astaire, J. C., R. Ward, J. B. German, and R. Jimenez-Flores. 2003. Concentration of polar MFGM lipids from buttermilk by microfiltration and supercritical fluid extraction. J. Dairy Sci. 86:2297-2307.

Chen, C. M., and M. E. Johnson. 2001. Pasta filata-simulative cheese product and method of making. Wisconsin Alumni Research Foundation, assignee. US Pat. No. RE37:264.

Corredig, M., and D. G. Dalgleish. 1998. Buttermilk properties in emulsions with soybean oil as affected by fat globule membranederived proteins. J. Food Sci. 63:476-477.

Corredig, M., R. R. Roesche, and D. G. Dalgleish. 2003. Production of a novel ingredient from buttermilk. J. Dairy Sci. 86:2744-2750.

Danthine, S., C. Blecker, M. Paquot, N. Innocente, and C. Deroanne. 2000. Progress in milk fat globule membrane research: A review. Lait 80:209-222.

Deeth, H. C. 1997. The role of phospholipids in the stability of milk fat globules. Aust. J. Dairy Technol. 52:44-46.

Dolan, S. P., and S. G. Capar. 2002. Multi-element analysis of food by microwave digestion and inductively coupled plasma-atomic emission spectrometry. J. Food Compos. Anal. 15:593-615.

Govindasamy-Lucey, S., J. J. Jaeggi, M. E. Johnson, T. Wang, and J. A. Lucey. 2005. Use of cold ultrafiltered retentates for standardization of milks for pizza cheese: Impact on yield and functionality. Int. Dairy J. 15:941-955.

Govindasamy-Lucey, S., T. Lin, J. J. Jaeggi, M. E. Johnson, and J. A. Lucey. 2006. Influence of condensed sweet cream buttermilk on the manufacture, yield and functionality of pizza cheese. J. Dairy Sci. 89:454-467.

Green, W. C., and K. K. Park. 1980. Comparison of AOAC, microwave and vacuum oven methods for determining total solids in milk. J. Food Prot. 4:728-783.

Huwiler, A., T. Kolter, J. Pfeilshifter, and K. Sandhoff. 2002. Physiology and pathophysiology and sphingolipid metabolism and signaling. Biochim. Biophys. Acta 1485:63-99.

Johnson, M. E., and N. F. Olson. 1985. A comparison of available methods for determining salt levels in cheese. J. Dairy Sci. 68:1020-1024.

Joshi, N. J., and P. N. Thakar. 1993. Utilization of buttermilk in manufacture of buffalo milk Cheddar cheese: Changes during ripening. J. Food Sci. Technol. 30:172-175.

Lawrence, R. C. 1987. The use of ultrafiltration technology in cheesemaking. IDF Bull. No. 240. Int. Dairy Fed., Brussels, Belgium.

Leaver, J., A. J. R. Law, D. S. Horne, and J. M. Banks. 1995. Influence of heating regime and $\mathrm{pH}$ on the primary phase of renneting of whole milk. Int. Dairy J. 5:129-140.

Lin, T. 2003. Investigation into the use of sweet cream buttermilk as an ingredient in cheese. MS Thesis. Univ. of Wisconsin-Madison.

Lucey, J. A., M. E. Johnson, and D. S. Horne. 2003. Perspectives on the basis of rheology and texture properties of cheese. J. Dairy Sci. 86:2725-2743.
Madsen, F. M., G. W. Reinbold, and W. S. Clark. 1966. Low-fat cheese. Manuf. Milk Prod. J. 57:18-21.

Marshall, R. T. 1992. Standard Methods for the Examination of Dairy Products. 16th ed. Am. Public Health Assoc. Inc., Washington, DC.

Mayes, J. J., G. Urbach, and B. J. Sutherland. 1994. Does addition of buttermilk affect the organoleptic properties of low fat Cheddar cheese? Aust. J. Dairy Technol. 49:39-42.

Mead, D., and P. Roupas. 2001. Effect of incorporation of denatured whey proteins on chemical composition and functionality of pizza cheese. Aust. J. Dairy Technol. 46:9-23.

Mistry, V. V., L. E. Metzger, and J. L. Maubois. 1996. Use of ultrafiltered sweet buttermilk in the manufacture of reduced fat Cheddar cheese. J. Dairy Sci. 79:1137-1145.

Modrak, D. E., D. M. Rodriguez, W. Goldenberg, and D. Blumenthal. 2002. Sphingomyelin enhances chemotherapy efficacy and increases apoptosis in human colonic tumor xenografts. Int. J. Oncol. 20:379-384.

Mounsey, J. S., and E. D. O'Riordan. 1999. Empirical and dynamic rheological data correlation to characterize melt characteristics of imitation cheese. J. Food Sci. 64:701-703.

Muthukumarappan, K., Y. C. Wang, and S. Gunasekaran. 1999. Estimating softening point of cheese. J. Dairy Sci. 82:2280-2286.

Nakanishi, T., and K. Kaya. 1970. Phospholipid of milk. II. Changes in phospholipids of milk by heating. Rakuno Kagaku No Kenkyu 19:7-10.

Nava, V. E., L. C. Cuvillier, K. Edsall, S. Kimura, E. P. Milstien, and S. Spiegel. 2000. Sphingosine enhances apoptosis of radiationresistant prostate cancer cells. Cancer Res. 60:4468-4474.

Poduval, V. S., and V. V. Mistry. 1999. Manufacture of reduced fat Mozzarella cheese using ultrafiltered sweet buttermilk and homogenized cream. J. Dairy Sci. 82:1-9.

Raval, D. M., and V. V. Mistry. 1999. Application of ultrafiltered sweet buttermilk in the manufacture of reduced fat process cheese. J. Dairy Sci. 82:2334-2343.

Rombaut, R., J. V. Camp, and K. Dewettinck. 2006. Phospho- and sphingolipid distribution during processing of milk, butter and whey. Int. J. Food Sci. Technol. 41:435-443.

Rosenberg, M., Z. Wang, S. L. Chuang, and C. F. Shoemaker. 1995. Viscoelastic property changes in cheddar cheese during ripening. J. Food Sci. 60:640-644.

Sachdeva, S., and W. Buchheim. 1997. Recovery of phospholipids from buttermilk using membrane processing. Kieler Michwirtschaftliche Forschungsberichte 49:47-68.

SAS Institute. 2003. SAS User's Guide: Statistics. Version 9.1 ed. SAS Inst. Inc., Cary, NC.

Sharma, K. C., J. Kaur, and S. Singh. 1994. Skim milk membrane lipids in relation to cool-aging and heat treatment of buffalo milk. Ind. J. Dairy Sci. 47:337-340.

Sutheerawattanonda, M., and E. D. Bastian. 1998. Monitoring process cheese meltability using dynamic oscillatory rheometry. J. Texture Stud. 29:169-183.

van Boekel, M. A. J. S. 1993. Transfer of milk components to cheese: Scientific considerations. Pages 19-28 in Cheese Yield and Factors Affecting Its Control. Int. Dairy Fed., Brussels, Belgium.

Van Slyke, L. L., and W. V. Price. 1936. Cheese. Orange Judd Publishing Co. Inc., New York, NY. 